\title{
REAKSI HARGA SAHAM DI PASAR MODAL INDONESIA TERHADAP PERISTIWA TEROR BOM PERIODE 2002-2017
}

\author{
Carissa Cindy F, \\ Carissacindy@gmail.com \\ Jurusan Akuntansi Program S2 Universitas Airlangga \\ Noorlailie Soewarno \\ noorlailie@gmail.com \\ Jurusan Akuntansi Program S2 Universitas Airlangga
}

\begin{abstract}
This research aims to determine the reaction of stock prices in Indonesia stock ecxchange when event of terror bombs. This research use event study where observation to window period of abnormal return during 5 days before, event date, and 5 days after the event. The data was collected from the Indonesia stock exchange by using daily closing price of stock price and JCI (Jakarta Composite Index). The population are event of terror boms period 2002-2017. The sampling technique in this research used purposive sampling with the criterias are the largest number of victims and the availability of data.The statistic instrument test has been done by using paired sample t-test and SPSS $24^{\text {rd }}$ program. The results show that there is the effect of bomb terrorism on stock price reaction in Indonesia stock exchange indicated by the differences of abnormal return. The influential incident that occurred during the bombing of Indonesia's history in Bomb Bali I at 2002, with the passage of time and the number of bombing events, investors have been sensitive to the occurrence of bomb explosion events against stock prices in the Indonesian capital market.
\end{abstract}

Keywords: Event study, terror boms, abnormal return, Indonesia stock exchange

\section{PENDAHULUAN}

Aksi teror atau terorisme, seringkali terjadi di dunia tak terkecuali Indonesia. Bentuk teror macam-macam berupa intimidasi, ancaman, pembunuhan, penganiayaan, pengeboman, dan lain sebagainya. Dampaknya pun sangat beragam, antara lain menimbulkan rasa kepanikan, takut, kekhawatiran bahkan kematian. Serangan teror secara langsung memiliki dampak negatif pada sejumlah sektor dan aktivitas ekonomi termasuk pasar modal. Dalam waktu singkat, serangan teror berpengaruh signifikan negatif pada perekonomian negara manapun. Hampir semua variabel ekonomi makro seperti investasi dalam negeri dan investasi asing sangat dipengaruhi oleh serangan teroris (Abadie \& Gardeazabal, 2008). Hal ini karena ketika peristiwa teror terjadi, mampu menciptakan rasa ketidakpercayaan dari investor lokal maupun asing.

Pasar modal sebagai salah satu instrumen ekonomi sangat dipengaruhi oleh berbagai peristiwa yang memiliki kandungan informasi. Sebuah peristiwa akan memiliki kandungan informasi apabila peristiwa tersebut dapat mempengaruhi harga saham yang kemudian mengakibatkan investor akan merubah dan mempertimbangkan kembali keputusannya (Sjahrir, 1995). Besarnya pengaruh suatu peristiwa terhadap kondisi pasar 
modal dapat dilihat melalui perubahan harga saham. Reaksi harga saham atas peritiwa tersebut dapat diukur dari abnormal return. Abnormal Return adalah selisih antara return sesungguhnya dengan return ekspektasi. Peristiwa yang memiliki kandungan informasi maka akan memberikan abnormal return bagi investor, sebaliknya apabila peristiwa yang tidak memiliki kandungan informasi maka tidak akan memberikan abnormal return bagi investor (Hartono, 2010). Efficient market theory menurut Ang (1997) menjadi dasar penelitian ini karena pasar yang efisien memiliki investor yang berpengetahuan Iuas atas informasi dan bereaksi cepat atas informasi tersebut, sehingga dapat mempertimbangkan dalam berinvestasi. Suatu pasar modal dikatakan efisien dapat dilihat dari stock return dan harga saham suatu pasar modal yang terdampak dari adanya suatu informasi.

Kondisi pasar modal dapat dipengaruhi oleh faktor eksternal dan internal. Salah satu faktor eksternal yang dapat mempengaruhi kondisi pasar adalah faktor politik yakni adanya peristiwa peledakan bom. Di Indonesia sepanjang periode 2002 sampai dengan 2017, telah mengalami banyak peristiwa peledakan bom. Bom terdahsyat sepanjang sejarah di Indonesia terjadi pada tahun 2002, tepatnya ketika terjadi ledakan Bom Bali I pada tanggal 12/10/2002. Bom tersebut mengakibatkan banyak korban jiwa, yaitu sebanyak 202 korban jiwa meninggal dan 209 orang luka-luka, sebagian besar korban tersebut adalah warga negara asing. Peristiwa peledakan terakhir di Indonesia terjadi pada tahun 2017, tepatnya ketika terjadi ledakan di Kampung Melayu pada tanggal 24/05/2017. Bom tersebut tertuju dengan target petugas kepolisian sebagai korban. Dari kejadian peristiwa peledakan bom yang terjadi di Indonesia dapat berpengaruh terhadap pasar modal dengan beberapa bukti dibawah ini:

Tabel 1 Dampak Peristiwa terhadap IHSG

\begin{tabular}{|l|c|c|}
\hline \multicolumn{1}{|c|}{ Peristiwa } & Sebelum & Saat \\
\hline 1. Bom Bali I (12/10/2002) & 376,46 & 337,47 \\
\hline 2. Bom JW Marriot (05/08/2003) & 503,94 & 488,52 \\
\hline 3. Bom Kedubes Australia (09/09/2004) & 789,13 & 782,65 \\
\hline 4. Bom Mega Kuningan (17/07/2009) & 2117,95 & 2106,35 \\
\hline 5. Bom Sarinah (14/01/2016) & 4537,18 & 4513,18 \\
\hline 6. Bom Kampung Melayu (24/05/2017) & 5730,61 & 5703,43 \\
\hline
\end{tabular}

Sumber: (idx.co.id., 2017)

Dari tabel diatas, maka dapat dilihat penurunan IHSG berdasarkan terjadinya suatu peristiwa. Faktanya bom Bali I pada 12/10/2002 mengakibatkan IHSG menurun 10\% dari 376,46 menjadi 337,47; bom JW Marriot 05/08/2003 mengakibatkan IHSG menurun 3\% dari 503,94 menjadi 488,52; bom Kedubes Australia 09/09/2004 mengakibatkan IHSG menurun $1 \%$ dari 789,13 menjadi 782,65; bom Mega Kuningan 17/07/2009 mengakibatkan IHSG menurun $0,5 \%$ dari 2117.95 menjadi 2106.35; bom Sarinah 14/01/2016 mengakibatkan IHSG menurun 0,5\% dari 4537,18 menjadi 4513,18; terakhir bom terjadi di Kampung melayu 24/05/2017 mengakibatkan IHSG menurun 0,5\% dari 5730.61 menjadi 5703.43 (idx.co.id., 2017). Artinya suatu peristiwa dapat berpengaruh terhadap pasar modal di Indonesia. Beberapa penelitian terdahulu Hassan, et al (2014), Christofis, et al (2013), Kollias, et al (2011), Fathi \& Shahraki (2011), Chen \& Siems (2004) juga menjelaskan bahwa suatu peristiwa dapat mempengaruhi pasar modal negara. Penelitian tersebut menjelaskan bahwa semakin besar kekerasan pada suatu peristiwa maka semakin besar pula dampaknya terhadap pasar modal. Tetapi penelitian Hassan, et al (2015) memiliki hasil yang berbeda bahwa suatu peristiwa tidak mempengaruhi pasar 
modal Pakistan periode 2003-2015 dikarenakan para investor telah mati rasa terhadap serangan teroris.

Berdasarkan uraian diatas, maka penelitian ini akan membuktikan apakah terror bom di Indonesia memberikan dampak pada pasar modal di dalam negeri selama periode 2002-2017. Kontribusi dengan adanya penelitian ini, untuk mengetahui pengaruh peristiwa teror bom di pasar modal Indonesia, sehingga para investor juga dapat mempelajari adanya informasi dari sebuah peristiwa yang dapat menentukan keputusannya dalam berinvestasi. Keterbaharuan penelitian ini adalah mengetahui dampak peristiwa peledakan bom di Indonesia terhadap pasar modal Indonesia periode 2002-2017, yang sebelumnya sudah diterapkan di pasar modal negara lain.

\section{KAJIAN PUSTAKA}

\section{Efficient Market Hypothesis (EMH)}

Pasar disebut efisien jika harga-harga saham mencerminkan seluruh informasi yang tersedia secara penuh dan cepat. Informasi tersebut tidak terbatas hanya pada informasi keuangan saja, tetapi juga mencakup informasi politik, kejadian sosial dan ekonomi, dan informasi lainnya. Konsep pasar efisien membahas bagaimana pasar merespon informasi dan mempengaruhi harga sekuritas. Fama (1970) menjelaskan mengenai pasar efisien yaitu pasar yang mencerminkan semua informasi yang tersedia. Hartono (2010) menyebutkan bahwa kondisi pasar yang efisien adalah jika pasar bereaksi dengan cepat untuk mencapai harga keseimbangan baru yang sepenuhnya mencerminkan informasi yang tersedia. Ada tiga bentuk tingkat efisiensi pasar (EMH) berdasarkan penyerapan informasinya, yaitu:

1. Efisien dalam bentuk lemah (weak form).

Pasar digolongkan bentuk lemah jika harga saham sepenuhnya mencerminkan semua informasi berdasarkan harga, volume penjualan, maupun laba masa lalu (historis). Harga saham yang lalu tidak dapat digunakan untuk memprediksi harga saham di masa yang akan datang.

2. Efisien dalam bentuk setengah kuat (semi-strong form)

Pasar digolongkan bentuk setengah kuat jika semua informasi publik yang tersedia tercermin dalam harga pasar. Informasi tersebut dapat berupa harga masa lalu, data fundamental perusahaan, prediksi laba, dan praktik akunting. Jika investor mendapatkan informasi publik tersebut maka akan dicerminkan dalam harga pasar.

3. Efisien dalam bentuk kuat (strong form)

Pasar digolongkan bentuk kuat jika harga sepenuhnya mencerminkan seluruh CAPM informasi, baik data historis, informasi publik maupun informasi privat."

Model CAPM diperkenalkan oleh Treynor, Sharpe dan Litner adalah sebuah model yang menggambarkan hubungan antara risiko dan return yang diharapkan, model ini digunakan dalam penilaian harga sekuritas. Model CAPM sebagai pengembangan teori portofolio yang dikemukan oleh Markowitz memperkenalkan istilah yaitu risiko sistematik (systematic risk) dan risiko spesifik/risiko tidak sistematik (spesific risk /unsystematic risk). Bodie, et al (2014) menjelaskan bahwa Capital Asset Pricing Model (CAPM) memberikan prediksi yang tepat antara hubungan risiko sebuah aset dan tingkat harapan pengembalian (expected return). Hubungan ini mempunyai dua fungsi penting yaitu. Pertama, menyediakan tolak ukur tingkat return yang diharapkan untuk mengevaluasi alternatif investasi yang mungkin dipilih. Kedua, model ini akan membantu membuat dugaan 
mengenai return yang diharapkan atas aset yang belum diperdagangkan dipasar. Hubungannya terkadang disebut model pasar (atau model indeks pasar) dapat dinyatakan sebagai berikut:

$$
\mathbf{R}_{\mathrm{it}}=\alpha_{\mathrm{i}}+\beta_{\mathrm{i}} \mathbf{R}_{\mathrm{mt}}+\mathbf{e}_{\mathrm{it}}
$$

Keterangan:

$\mathrm{R}_{\text {it }} \quad=$ pengembalian atas aktiva $\mathrm{i}$ selama periode $\mathrm{t}$

$\mathrm{R}_{\mathrm{mt}} \quad=$ pengembalian portofolio pasar selama periode $\mathrm{t}$

$\alpha_{i} \quad=$ simbol yang menunjukkan komponen pengembalian aktiva $\mathrm{i}$ terhadap perubahan dalam portofolio pasar

$\beta_{\mathrm{i}} \quad=$ simbol yang menghubungkan perubahan pengembalian aktiva $\mathrm{i}$ terhadap perubahan dalam portofolio pasar

$\mathrm{e}_{\mathrm{it}} \quad=$ simbol kesalahan acak yang merefleksikan resiko unik yang berhubungan dengan menanamkan modal dalam suatu aktiva

\section{Abnormal Return}

Reaksi pasar akibat terjadinya suatu peristiwa biasanya mengamati perubahan harga saham yang diukur dengan adanya abnormal return. Abnormal return atau excess return merupakan kelebihan dari return yang sesungguhnya terjadi terhadap return normal. Return normal merupakan return ekspektasi (yang diharapkan oleh investor) dengan mempertimbangkan tingkat resikonya. Dengan demikian return tidak normal (abnormal return) adalah selisih antara actual return dengan return ekspektasi. Apabila Suatu pengumuman memiliki kandungan informasi, maka akan memberikan abnormal return kepada pasar. Sebaliknyam, apabila suatu pengumuman tidak memiliki kandungan informasi, maka tidak akan memberikan abnormal return kepada pasar. Abnormal return saham pada hari ke $t$ dapat di hitung dengan mempergunakan rumus sebagai berikut (Hartono, 2010: 107)

$$
\text { Arit }=\text { Rit }-\mathbf{E}(\text { Rit })
$$

Keterangan:

ARit = abnormal return saham 1 pada hari ke $\mathrm{t}$

Rit = actual return saham 1 pada hari ke $\mathrm{t}$

$\mathrm{E}($ Rit $)=$ ekspected return saham 1 pada hari ke $\mathrm{t}$.

\section{Hubungan Peristiwa dengan Pasar Saham}

Efficient Market Hypotesis menjelaskan respon suatu informasi terhadap harga saham, yaitu bagaimana suatu informasi dapat mempengaruhi harga saham. Dalam hipotesa pasar efisien, maka pasar akan merespon dengan cepat adanya suatu informasi. Fama (1970) membuktikan bahwa adanya informasi stock split sangat besar hubungannya dengan peningkatan deviden. Terbukti bahwa informasi pengumuman stock split memberikan dampak pada pendapatan perlembar saham yang diharapkan oleh investor. Selanjutnya dapat dibuktikan bahwa informasi adanya stock split memberikan dampak pada rata-rata perhatian pasar atas informasi dan implikasi atas stock split keseluruhan dalam harga saham setelah pengumuman. Demikian halnya Mandelbrot (1966) dan Samuelson (1965) yang mampu membuktikan bahwa harga saham berubah secara bebas sebagai akibat adanya pengaruh informasi pada pasar efisien. Artinya bahwa pasar saham pada pasar efisien menunjukkan bahwa harga saham terpengaruh dengan adanya pengulangan informasi.

Dari uraian diatas dapat disimpulkan bahwa pada pasar efisiensi, pasar saham akan merespon dengan cepat adanya suatu informasi yang berdampak pada harga dan tingkat pengembalian atau keuntungan yang diharapkan atas suatu saham. Dalam penelitian ini informasi yang dipergunakan adalah teror bom yang terjadi belahan dunia dibeberapa 
negara yang berdampak pada pasar saham. Banyak penelitian di masa lalu yang meneliti respon perilaku pasar saham terhadap peristiwa serangan teroris (Sandler, 2003; Sandler \& Enders, 2004; Bruck \& Wickstrom, 2004; Bruck, 2005; Brounen \& Derwall, 2010). Karena sudah dibuktikan oleh beberapa penelitian yang menunjukkan bahwa teroris dapat mempengaruhi pasar modal skala besar dalam jangka waktu yang singkat. Adanya pengaruh langsung antara kegiatan teroris dengan sentimen investor menyebabkan terjadinya penurunan pasar saham. Karena investor menjadi defensif dalam fase ketidakpastian yang disebabkan oleh peristiwa dan hasil dalam fluktuasi harga pasar di Bursa (Drakos, 2010). Selanjutnya Hon, et al (2004) dan Nikkinen, et all (2006) menyatakan bahwa serangan 9/11 World Trade Centre adalah peristiwa pertama yang menarik perhatian para peneliti untuk mempelajari respon terorisme terhadap pasar modal. Dari uraian diatas dapat disimpulkan bahwa hubungan antara peristiwa teroris dengan pasar saham adalah sangat erat, yaitu adanya peristiwa teroris dapat mempengaruhi pasar saham.

\section{Event study}

Ball \& Brown (1968) memperkenalkan metodologi event study untuk penelitian tentang kegunaan informasi. Sementara Fama (1970) menggunakan event study untuk penelitian tentang efisiensi pasar. Studi yang banyak dilakukan atas dampak pengumuman terhadap harga saham adalah event study (Elton, 2009). Event study digunakan untuk menguji kandungan informasi dari suatu peristiwa atau pengumuman. Jika suatu peristiwa atau pengumuman mengandung informasi maka pasar akan bereaksi pada waktu pengumuman tersebut diterima oleh pasar. Reaksi pasar ditunjukkan dengan adanya perubahan harga sekuritas bersangkutan. Reaksi ini biasanya diukur dengan menggunakan konsep abnormal return. Suryawijaya \& Setiawan (1998) juga menjelaskan bahwa Event study adalah suatu pengamatan mengenai pergerakan harga saham di pasar modal untuk mengetahui apakah ada abnormal return yang diperoleh pemegang saham akibat dari suatu peristiwa tertentu.

\section{Penelitian Terdahulu}

Teror bom merupakan peristiwa mencekam yang dapat mempengaruhi pasar modal suatu Negara. Demikian halnya dengan terror bom yang terjadi di Indonesia selama periode tahun 2002-2017. Dengan banyaknya peledakan bom yang terjadi di Indonesia, bom terdahsyat ketika terjadi pada tanggal 12/10/2002 yaitu Bom Bali I, sebagian besar korbannya adalah warga Negara asing yang ada di Indonesia. Peristiwa ledakan terakhir di Indonesia terjadi pada tanggal 24/05/2017, tepatnya di halte kampung melayu dengan target dan korban petugas kepolisian. Beberapa penelitian berikut ini mampu membuktikan adanya dampak negatif peristiwa terror pada pasar modal.

Hipotesis dalam penelitian ini merupakan pengembangan dari beberapa hasil penelitian terdahulu. Penelitian Hassan, et al (2014) meneliti dampak serangan teroris di Pakistan terhadap Karachi Stock Exhange periode 2001-2010 menggunakan metodologi event study, hasilnya adalah serangan hotel Marriott menghasilkan dampak negative di seluruh waktu peristiwa, serangan pembunuhan mantan Perdana Menteri Benazir Bhutto mengakibatkan penurunan tajam yang diikuti dengan pemulihan indeks KSE 100, sementara ada sedikit dampak negatif dari serangan Darra Adamkhel terhadap Indeks KSE 100 yang juga bertahan selama satu atau dua hari. Artinya ada pengaruh negatif terorisme pada pasar modal Pakistan. Penelitian Christofis, et al (2013) yang meneliti dampak serangan teroris di Istanbul-Turkey terhadap Istanbul Stock Exchange (ISE) periode 1997-2009, serangan teroris pada shopping mall 13/03/1999, serangan teroris pada British Consulate \& HSBC bank headquarters 20/11/2003, dan serangan teroris pada 
shopping street 27/07/2008, ketiga serangan teroris terbesar yang telah terjadi selama periode penelitian memberikan hasil bahwa serangan tersebut berdampak negative terhadap pasar modal Turkey. Dari penjelasan diatas mengenai dampak peristiwa bom terhadap pasar modal, maka hipotesis dalam penelitian ini adalah sebagai berikut:

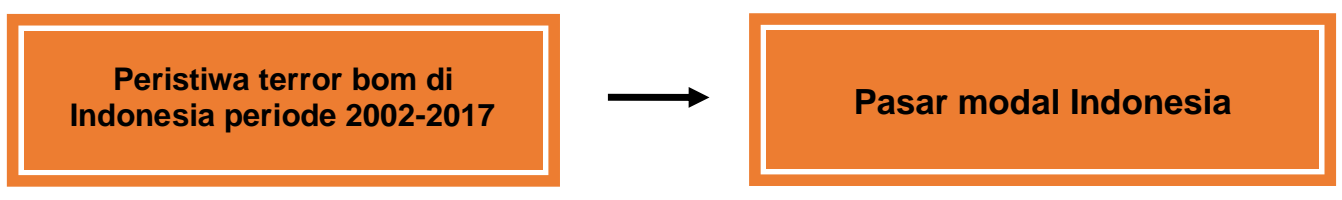

H1:Peristiwa teror bom berpengaruh terhadap pasar modal di Indonesia.

\section{METODE PENELITIAN}

Penelitian ini merupakan studi peristiwa (event study). Studi peristiwa menurut Hartono (2010) merupakan studi yang mempelajari reaksi pasar modal atas suatu peristiwa yang informasinya dipublikasikan sebagai suatu pengumuman. Dalam penelitian ini peristiwa yang terjadi adalah peristiwa terror bom di Indonesia dengan menilai reaksi pasar berdasarkan perubahan abnormal return.

Populasi yang digunakan adalah peristiwa teror bom mulai periode tahun 2002 hingga 2017 yaitu sebanyak 30 peristiwa (Anonim, 2017). Sampel adalah bagian dari populasi yang digunakan untuk mewakili dari keseluruhan populasi. Teknik penentuan sampel dalam penelitian ini adalah purposive sampling, yaitu penentuan sampel berdasarkan pada kriteria khusus, yaitu: Peristiwa terror bom dengan jumlah korban terbanyak yang memiliki data closing price harian dan data indeks harga saham gabungan harian. Periode pengamatan waktu yang dibutuhkan untuk data suatu peristiwa yaitu 5 hari sebelum peristiwa(t-5), waktu peristiwa(t0), 5 hari setelah petistiwa $(t+5)$, dan 90 hari sebelum peristiwa (t-90) untuk periode estimasi.

Jenis data yang digunakan dalam penelitian ini adalah data kuantitatif dan sumber data dalam penelitian ini adalah data sekunder. Teknik pengumpulan data yang digunakan dalam penelitian ini adalah teknik dokumentasi, yaitu teknik pengumpulan data melalui pencatatan data harga pasar modal saat penutupan (closing price) dan indeks harga saham sesuai dengan periode peristiwa. Data yang dipergunakan dalam penelitian ini adalah data sekunder yang bersumber dari web resmi pasar modal indonesia http://www.idx.co.id. Teknik analisis data yang digunakan dalam penelitian ini adalah uji beda atau paired sample t test. Alat yang digunakan untuk menghitung pengujian hipotesis dengan bantuan aplikasi program SPSS versi 24.

\section{HASIL DAN PEMBAHASAN \\ Peristiwa Peledakan Bom Di Indonesia 2002-2017}

Bom terbesar selama sejarah di Indonesia pada waktu Bom Bali I pada tanggal 12/10/2002. Bom tersebut juga mengakibatkan 202 orang meninggal dan 209 orang lukaluka, korban pun banyak berasal dari wisatawan warga asing dan juga ada warga lokal. Ditahun berikutnya juga terjadi ledakan bom besar yang mengakibatkan korban jiwa tepatnya pada tanggal 05/08/2003 di Hotel JW Marriott, Jakarta. Ledakan tersebut menyebabkan 11 orang meninggal dan 152 orang luka-luka. Ditanggal 09/09/2004 juga terjadi ledakan bom di depan pintu masuk Gedung Kedutaan Besar Australia Kavling C15-16, jalan H.R. Rasuna Said, Kuningan, Jakarta Selatan. Bom tersebut menyebabkan 10 orang meninggal dan 182 orang luka-luka. Bom di kawasan Mega Kuningan yang terjadi pada tanggal 17/07/07/2009 terjadi di hotel JW Marriott dan hotel Ritz-Carlton. 
Ledakan tersebut menyebabkan 9 orang meninggal dan 53 orang luka-luka. Peristiwa bom terakhir yang juga mengakibatkan banyak korban pada tanggal 14/01/2016 ketika terjadi Bom Sarinah di Jakarta. Selain para pelaku teror, ada pula empat korban warga sipil yang meninggal dunia dan 25 korban yang mengalami luka-luka (Anonim, 2017).

\section{Actual Retutrn - Rit}

Actual Return, adalah tingkat pengembalian dari seluruh investasi dalam periode tertentu. Dalam perhitungan actual return periode peristiwa tidak menggunakan deviden, karena pembayaran deviden dilakukan pada periode tahunan. Actual Return diukur dengan satuan (\%). Untuk melihat hasil penghitungan Actual Return selama periode peristiwa ( $\mathrm{t}-5$ sampai dengan $\mathrm{t}+5$ ) dapat dilihat tabel 2 di bawah ini.

Tabel 2 Actual Return Peristiwa

\begin{tabular}{|c|r|r|r|r|r|}
\hline Periode & $\begin{array}{c}\text { Bom } \\
\text { Bali I } \\
(\mathbf{1 2 / 1 0 / 2 0 0 2})\end{array}$ & $\begin{array}{c}\text { Bom JW } \\
\text { Marriot } \\
\mathbf{( 0 5 / 0 8 / 2 0 0 3 )}\end{array}$ & $\begin{array}{c}\text { Bom } \\
\text { Kedubes } \\
\text { Australia } \\
(\mathbf{0 9 / 0 9 / 2 0 0 4 )}\end{array}$ & $\begin{array}{c}\text { Bom Mega } \\
\text { Kuningan } \\
\mathbf{( 1 7 / 0 7 / 2 0 0 9 )}\end{array}$ & $\begin{array}{c}\text { Bom } \\
\text { Sarinah } \\
(\mathbf{1 4 / 0 1 / 2 0 1 6})\end{array}$ \\
\hline+5 & 0.006 & 0.001 & 0.005 & 0.011 & -0.002 \\
\hline+4 & 0.018 & -0.005 & -0.001 & 0.009 & -0.014 \\
\hline+3 & -0.007 & 0.005 & 0.009 & 0.017 & 0.002 \\
\hline+2 & 0.035 & 0.028 & 0.011 & -0.009 & -0.009 \\
\hline+1 & 0.010 & 0.013 & 0.019 & 0.020 & 0.003 \\
\hline 0 & -0.088 & -0.037 & -0.009 & -0.006 & -0.005 \\
\hline-1 & -0.016 & -0.001 & 0.006 & 0.003 & 0.004 \\
\hline-2 & -0.016 & 0.010 & 0.007 & 0.033 & 0.008 \\
\hline-3 & -0.023 & 0.004 & -0.003 & 0.017 & -0.017 \\
\hline-4 & 0.003 & 0.000 & 0.005 & -0.019 & 0.002 \\
\hline-5 & -0.017 & 0.003 & 0.002 & -0.008 & -0.016 \\
\hline
\end{tabular}

Sumber: (data diolah peneliti, 2017)

\section{Return Market - Rmt}

Return Market, adalah perbandingan atas nilai indeks harga saham gabungan nilai hari sekarang (t) dengan nilai indeks harga saham gabungan nilai kemarin (t-1). Return Market diukur dengan satuan (\%). Untuk melihat hasil penghitungan Return Market selama periode peristiwa ( $\mathrm{t}-5$ sampai dengan $\mathrm{t}+5$ ) dapat dilihat tabel 3 di bawah ini.

Tabel 3 Return Market Peristiwa

\begin{tabular}{|c|r|r|r|r|r|}
\hline Periode & $\begin{array}{c}\text { Bom } \\
\text { Bali I } \\
(\mathbf{1 2 / 1 0 / 2 0 0 2 )}\end{array}$ & $\begin{array}{c}\text { Bom JW } \\
\text { Marriot } \\
\mathbf{( 0 5 / 0 8 / 2 0 0 3 )}\end{array}$ & $\begin{array}{c}\text { Bom } \\
\text { Kedubes } \\
\text { Australia } \\
\mathbf{( 0 9 / 0 9 / 2 0 0 4 )}\end{array}$ & $\begin{array}{c}\text { Bom Mega } \\
\text { Kuningan } \\
(\mathbf{1 7 / 0 7 / 2 0 0 9})\end{array}$ & $\begin{array}{c}\text { Bom } \\
\text { Sarinah } \\
\mathbf{( 1 4 / 0 1 / 2 0 1 6 )}\end{array}$ \\
\hline+5 & 0.003 & 0.003 & 0.002 & 0.011 & -0.003 \\
\hline+4 & 0.016 & -0.001 & -0.003 & 0.012 & -0.014 \\
\hline+3 & -0.006 & -0.006 & 0.008 & 0.017 & 0.002 \\
\hline+2 & 0.044 & 0.028 & 0.014 & -0.010 & -0.009 \\
\hline+1 & 0.014 & 0.012 & 0.019 & 0.019 & 0.002 \\
\hline 0 & -0.104 & -0.031 & -0.008 & -0.005 & -0.005 \\
\hline-1 & -0.021 & -0.009 & 0.003 & -0.003 & 0.005 \\
\hline-2 & -0.019 & 0.001 & 0.002 & 0.032 & 0.011 \\
\hline
\end{tabular}


REAKSI HARGA SAHAM DI PASAR MODAL INDONESIA TERHADAP PERISTIWA TEROR BOM PERIODE 2002-2017

\begin{tabular}{|r|r|r|r|r|r|}
\hline-3 & -0.025 & 0.000 & -0.002 & 0.018 & -0.018 \\
\hline-4 & 0.001 & -0.006 & 0.008 & -0.021 & 0.003 \\
\hline-5 & -0.016 & -0.003 & 0.007 & -0.010 & -0.017 \\
\hline
\end{tabular}

Sumber: (data diolah peneliti, 2017)

\section{Expected Return - E(Rit)}

Return ekspektasi adalah return yang diharapkan diperoleh oleh investor dimasa mendatang. Berbeda dengan actual return yang sifatnya sudah terjadi, return ekspektasi sifatnya belum terjadi. Return ekspektasi merupakan return yang harus diestimasi. Dalam memproyeksikan tingkat keuntungan yang diharapkan (expected return) atas suatu saham dengan mempergunakan (market adjuxted models) yang menganggap bahwa return indeks pasar saat ini dapat dipergunakan untuk mengestimasi return suatu sekuritas. Di dalam market adjuxted models perlu memperhitungkan alpha dan beta yang merupakan koefisien yang dipergunakan untuk proyeksi dalam memperhitungkan expected return. Expected return diukur dengan satuan (\%). Untuk melihat hasil penghitungan Expected Return selama periode peristiwa ( $\mathrm{t}-5$ sampai dengan $\mathrm{t}+5$ ) dapat dilihat tabel 4 di bawah ini.

Tabel 4 Expected Return Peristiwa

\begin{tabular}{|c|r|r|r|r|r|}
\hline Periode & $\begin{array}{c}\text { Bom } \\
\text { Bali I } \\
(\mathbf{1 2 / 1 0 / 2 0 0 2 )})\end{array}$ & $\begin{array}{c}\text { Bom JW } \\
\text { Marriot } \\
(\mathbf{0 5 / 0 8 / 2 0 0 3 )}\end{array}$ & $\begin{array}{c}\text { Bom } \\
\text { Kedubes } \\
\text { Australia } \\
(\mathbf{0 9 / 0 9 / 2 0 0 4 )}\end{array}$ & $\begin{array}{c}\text { Bom Mega } \\
\text { Kuningan } \\
(\mathbf{1 7 / 0 7 / 2 0 0 9})\end{array}$ & $\begin{array}{c}\text { Bom } \\
\text { Sarinah } \\
(\mathbf{1 4 / 0 1 / 2 0 1 6})\end{array}$ \\
\hline+5 & 0.000 & 0.000 & 0.000 & 0.001 & 0.0001 \\
\hline+4 & 0.002 & 0.000 & 0.002 & 0.001 & 0.0002 \\
\hline+3 & -0.001 & -0.001 & -0.003 & 0.001 & 0.0000 \\
\hline+2 & 0.006 & 0.003 & -0.005 & 0.000 & 0.0002 \\
\hline+1 & 0.002 & 0.001 & -0.007 & 0.001 & 0.0000 \\
\hline 0 & -0.014 & -0.003 & 0.004 & 0.000 & 0.0001 \\
\hline-1 & -0.003 & -0.001 & -0.001 & 0.000 & 0.0000 \\
\hline-2 & -0.003 & 0.000 & 0.000 & 0.002 & -0.0001 \\
\hline-3 & -0.004 & 0.000 & 0.001 & 0.001 & 0.0003 \\
\hline-4 & 0.000 & -0.001 & -0.003 & 0.000 & 0.0000 \\
\hline-5 & -0.002 & 0.000 & -0.002 & 0.000 & 0.0003 \\
\hline
\end{tabular}

Sumber: (data diolah peneliti, 2017)

\section{Abnormal Return - AR}

Abnormal return adalah tingkat pengembalian tidak normal suatu investasi yang dilakukan pada masa periode peristiwa. Penghitungannya antara selisih antara Actual Return dengan Ekspected return. Abnormal return diukur dengan satuan (\%). Untuk melihat hasil penghitungan Abnormal Return selama periode peristiwa (t-5 sampai dengan $\mathrm{t}+5$ ) dapat dilihat tabel 5 di bawah ini.

Tabel 5 Abnormal Return Peristiwa

\begin{tabular}{|c|c|c|c|c|c|}
\hline \multirow{3}{*}{ Periode } & $\begin{array}{c}\text { Bom } \\
\text { Bali I } \\
(12 / 10 / 2002)\end{array}$ & $\begin{array}{c}\text { Bom JW } \\
\text { Marriot } \\
(05 / 08 / 2003)\end{array}$ & $\begin{array}{c}\text { Bom } \\
\text { Kedubes }\end{array}$ & $\begin{array}{c}\text { Bom Mega } \\
\text { Kuningan } \\
(17 / 07 / 2009)\end{array}$ & $\begin{array}{c}\text { Bom } \\
\text { Sarinah } \\
(14 / 01 / 2016)\end{array}$ \\
\hline
\end{tabular}


REAKSI HARGA SAHAM DI PASAR MODAL INDONESIA TERHADAP PERISTIWA TEROR BOM PERIODE 2002-2017

\begin{tabular}{|r|r|r|r|r|r|}
\hline & & & $\begin{array}{r}\text { Australia } \\
\mathbf{( 0 9 / 0 9 / 2 0 0 4 )}\end{array}$ & & \\
\hline+5 & 0.006 & 0.001 & 0.005 & 0.011 & -0.002 \\
\hline+4 & 0.016 & -0.005 & -0.003 & 0.009 & -0.014 \\
\hline+3 & -0.006 & 0.005 & 0.012 & 0.016 & 0.002 \\
\hline+2 & 0.029 & 0.026 & 0.016 & -0.009 & -0.009 \\
\hline+1 & 0.008 & 0.012 & 0.026 & 0.019 & 0.003 \\
\hline 0 & -0.074 & -0.034 & -0.013 & -0.006 & -0.005 \\
\hline-1 & -0.013 & 0.000 & 0.006 & 0.003 & 0.004 \\
\hline-2 & -0.013 & 0.010 & 0.008 & 0.031 & 0.008 \\
\hline-3 & -0.019 & 0.004 & -0.004 & 0.016 & -0.017 \\
\hline-4 & 0.003 & 0.001 & 0.008 & -0.019 & 0.002 \\
\hline-5 & -0.014 & 0.003 & 0.004 & -0.008 & -0.016 \\
\hline
\end{tabular}

Sumber: (data diolah peneliti, 2017)

\section{Pengujian Normalitas Data}

Sebelum melakukan uji statistik, langkah awal yang harus dilakukan adalah melakukan screening terhadap data yang akan diolah. Karena penelitian ini menggunakan alat analisis uji beda untuk sampel yang berhubungan (paired sample t-test) untuk pengujian hipotesis, maka asumsi yang dipergunakan adalah data terdistribusi normal. Untuk mendeteksi normalitas data dari masing-masing variabel, dipergunakan uji normalitas data (Kolmogorov-Smirnov test).

Jika hasil pengolahan data menghasilkan probabilitas signifikan diatas $5 \%(0,05)$ maka data terdistribusi secara normal. Sebaliknya jika hasil pengolahan data menghasilkan probabilitas signifikan dibawah 5\% $(0,05)$ maka data terdistribusi tidak normal. Apabila data tidak terdistribusi secara normal maka menggunakan statistik non parametrik Wilcoxon signed rank test.

Tabel 6 Hasil Uji Normalitas Data Abnormal Return

\begin{tabular}{|c|c|c|c|c|}
\hline No & Peristiwa & $\begin{array}{l}\text { Kolmogorov- } \\
\text { Smirnov } Z\end{array}$ & $\begin{array}{c}\text { Asymp. } \\
\text { Sig. (2-tailed) }\end{array}$ & Simpulan \\
\hline 1 & Bom Bali I (12/10/2002) & 0.629 & 0.824 & Normal \\
\hline 2 & $\begin{array}{l}\text { Bom JW } \\
(05 / 08 / 2003)\end{array}$ & 1.194 & 0.115 & Normal \\
\hline 3 & $\begin{array}{l}\text { Bom Kedubes Australia } \\
(09 / 09 / 2004)\end{array}$ & 0.700 & 0.711 & Normal \\
\hline 4 & $\begin{array}{l}\text { Bom Mega Kuningan } \\
(17 / 07 / 2009)\end{array}$ & 0.436 & 0.991 & Normal \\
\hline 5 & Bom Sarinah (14/01/2016) & 0.607 & 0.854 & Normal \\
\hline
\end{tabular}

Sumber: (data diolah peneliti, 2017)

Dari hasil uji normalitas pada tabel 6 dengan data abnormal return selama periode peristiwa ( $\mathrm{t}-5$ sampai dengan $\mathrm{t}+5$ ), maka seluruh peristiwa peledakan bom memiliki data abnormal return yang terdistribusi normal, karena hasil pengujian menujukkan bahwa nilai Asymp. Sig. (2-tailed) > 0,05 untuk statistik Kolmogorov-Smirnov. 


\section{Pengujian Hipotesis}

Analisis dalam penelitian ini menggunakan paired-sampel t test untuk mengetahui perbedaan abnormal return sebelum dan sesudah peristiwa peledakan bom terhadap reaksi harga saham di pasar modal Indonesia. Apabila hasil pengolahan data menghasilkan probabilitas signifikan dibawah 5\% $(0,05)$, maka abnormal return sebelum peristiwa memiliki perbedaan dengan abnormal return setelah peristiwa, sehingga dapat dinyatakan bahwa peristiwa peledakan bom dapat mempengaruhi harga saham di pasar modal Indonesia. Begitu sebaliknya, apabila hasil pengolahan data menghasilkan probabilitas signifikan lebih dari 5\% $(0,05)$, maka abnormal return sebelum peristiwa tidak memiliki perbedaan dengan abnormal return sesudah peristiwa, sehingga dapat dinyatakan bahwa peristiwa peledakan bom tidak dapat mempengaruhi harga saham di pasar modal Indonesia.

Tabel 7 Hasil Uji Paired-Sampel t Test Peristiwa

\begin{tabular}{|r|l|c|c|}
\hline No & \multicolumn{1}{|c|}{ Peristiwa } & Sig. (2-tailed) & Simpulan \\
\hline 1 & Bom Bali I (12/10/2002) & 0.010 & Berpengaruh \\
\hline 2 & Bom JW Marriot (05/08/2003) & 0.488 & Tidak Berpengaruh \\
\hline 3 & $\begin{array}{l}\text { Bom Kedubes Australia } \\
(09 / 09 / 2004)\end{array}$ & 0.043 & Berpengaruh \\
\hline 4 & Bom Mega Kuningan (17/07/2009) & 0.183 & Tidak Berpengaruh \\
\hline 5 & Bom Sarinah (14/01/2016) & 0.874 & Tidak Berpengaruh \\
\hline
\end{tabular}

Sumber: (data diolah peneliti, 2017)

Dari hasil uji paired-sample t test pada tabel 7, maka dapat dilihat hasil signifikasi dari peristiwa peledakan bom tidak semua perpengaruh terhadap pasar modal Indonesia. Hanya 2 peristiwa peledakan bom yang memiliki signifikansi dibawah 0.05 yaitu Bom Bali I dan Bom Kedubes Australia. Bom Bali I pada pada tanggal 12/10/2002 menunjukkan hasil signifikansi $0.010<0.05$, maka abnormal return sebelum peristiwa memiliki perbedaan dengan abnormal return setelah peristiwa, sehingga dapat dinyatakan bahwa peristiwa peledakan Bom Bali I dapat mempengaruhi harga saham di pasar modal Indonesia. Bom Kedubes Australia pada pada tanggal 09/09/2004 menunjukkan hasil signifikansi $0.043<0.05$, maka abnormal return sebelum peristiwa memiliki perbedaan dengan abnormal return setelah peristiwa, sehingga dapat dinyatakan bahwa peristiwa peledakan Bom Kedubes Australia dapat mempengaruhi harga saham di pasar modal Indonesia.

Sedangkan 3 peristiwa peledakan bom lain memiliki signifikansi diatas 0.05 yaitu Bom JW Mariot, Bom Mega Kuningan dan Bom Sarinah. Bom di hotel JW Marriot pada tanggal 05/08/2003 menunjukkan hasil signifikansi 0.489>0.05, Bom di kawasan Mega Kuningan pada tanggal 17/07/2009 menunjukkan hasil signifikansi $0.183>0.05$, dan Bom Sarinah pada tanggal 14/01/2006 menunjukkan hasil signifikansi $0.874>0.05$. Dari hasil penghitungan paired-sample t test pada ketiga peristiwa tersebut didapatkan hasil signifikansi $>0.05$, maka abnormal return sebelum peristiwa tidak memiliki perbedaan dengan abnormal return sesudah peristiwa, sehingga dapat dinyatakan bahwa peristiwa peledakan Bom JW Marriot, Bom Mega Kuningan dan Bom Sarinah tidak dapat mempengaruhi harga saham di pasar modal Indonesia pada periode peristiwa tersebut. 


\section{Pembahasan}

Dari pengujian hipotesis dengan menggunakan uji paired-sample t test, dapat terlihat bahwa adanya peristiwa yang memiliki abnormal return sebelum peristiwa berbeda dengan abnormal return setelah peristiwa, sehingga dapat dikatakan bahwa peristiwa peledakan bom dapat berpengaruh terhadap pasar modal Indonesia dalam periode peristiwa tersebut. Sesuai dengan teori yang digunakan sebagai acuan dalam penelitian ini, bahwa investor akan bereakasi dengan terhadap informasi dalam periode peristiwa sehingga dapat dikatakan sebagai pasar efisien. Pasar efisien yang terjadi dalam peristiwa ini digolongkan setengah kuat dikarenakan harga dari sekuritas akan mencerminkan semua informasi yang dipublikasian selama periode peristiwa kemudian investor akan menyerap informasi tersebut sebagai bahan pertimbangan pengambilan keputusan dalam berinvestasi di pasar modal Indonesia.

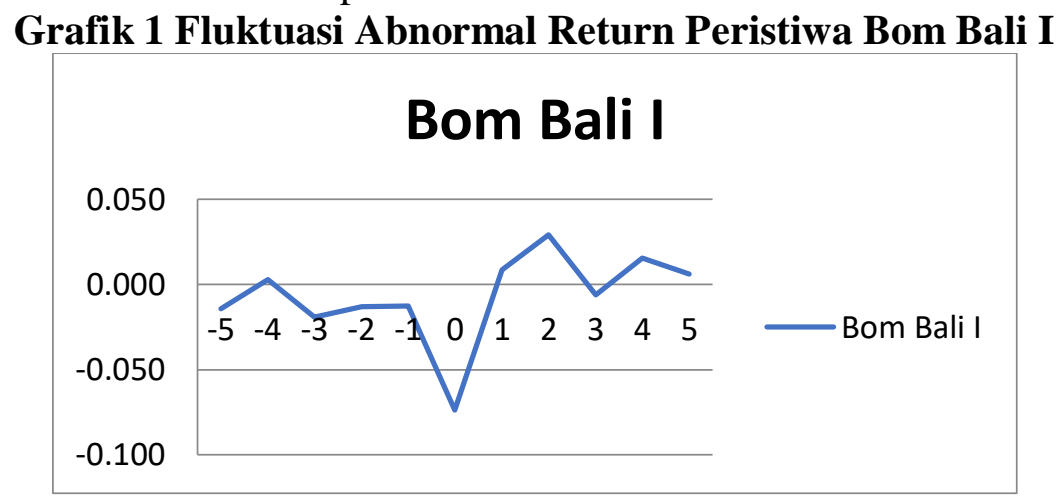

Sumber: (data diolah peneliti, 2017)

Grafik 1 memperlihatkan pergerakan abnormal return selama periode peristiwa Bom Bali I pada tanggal 12/10/2002. Grafik tersebut memperlihatkan bahwa ketika terjadi peristiwa peledakan Bom Bali I, abnormal return langsung merosot tajam dari hari sebelumnya yang bernilai -0.013 menjadi -0.074 , kemudian hari setelah peristiwa terjadi banyak peningkatan abnormal return menjadi 0.008 . Terlihat juga bahwa pergerakan abnormal return sebelum peristiwa memiliki perbedaan dengan pergerakan abnormal return setelah peristiwa. Dan hasil penghitungan uji hipotesis dengan paired-sample t test menyatakan bahwa Bom Bali I memiliki hasil signifikansi $0.010<0.05$, maka abnormal return sebelum peristiwa memiliki perbedaan dengan abnormal return setelah peristiwa, sehingga dapat dinyatakan bahwa peristiwa peledakan Bom Bali I dapat mempengaruhi harga saham di pasar modal Indonesia.

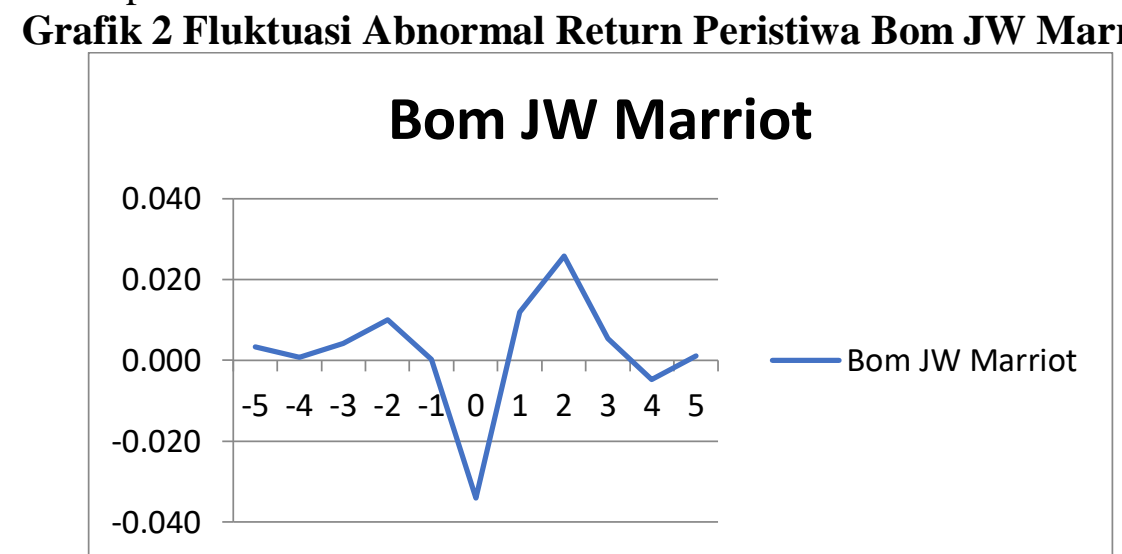

Sumber: (data diolah peneliti, 2017) 
Grafik 2 memperlihatkan pergerakan abnormal return selama periode peristiwa Bom JW Marriot pada tanggal 05/08/2003. Grafik tersebut memperlihatkan bahwa ketika terjadi peristiwa peledakan Bom JW Marriot, abnormal return langsung merosot tajam dari hari sebelumnya yang bernilai 0.000 menjadi -0.034 , kemudian hari setelah peristiwa terjadi banyak peningkatan abnormal return menjadi 0.012. Hasil penghitungan uji hipotesis dengan paired-sample t test menyatakan bahwa Bom JW Marriot memiliki hasil signifikansi $0.489>0.05$, maka abnormal return sebelum peristiwa tidak memiliki perbedaan dengan abnormal return sesudah peristiwa, sehingga dapat dinyatakan bahwa peristiwa peledakan Bom JW Marriot tidak dapat mempengaruhi harga saham di pasar modal Indonesia pada periode peristiwa tersebut.

\section{Grafik 3 Fluktuasi Abnormal Return Peristiwa Bom Kedubes Australia}

\section{Bom Kedubes Australia}

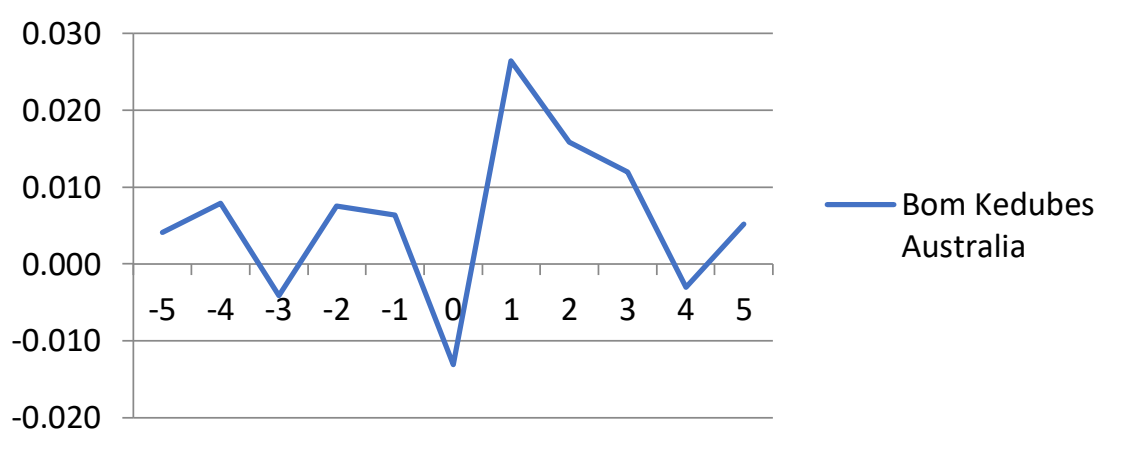

Sumber: (data diolah peneliti, 2017)

Grafik 3 memperlihatkan pergerakan abnormal return selama periode peristiwa Bom Kedubes Australia pada tanggal 09/09/2004. Grafik tersebut memperlihatkan bahwa ketika terjadi peristiwa peledakan Bom Kedubes Australia, abnormal return langsung merosot tajam dari hari sebelumnya yang bernilai 0.006 menjadi -0.013 , kemudian hari setelah peristiwa terjadi banyak peningkatan abnormal return menjadi 0.026 . Terlihat juga bahwa pergerakan abnormal return sebelum peristiwa memiliki perbedaan dengan pergerakan abnormal return setelah peristiwa. Dan hasil penghitungan uji hipotesis dengan paired-sample t test menyatakan bahwa Bom Kedubes Australia memiliki hasil signifikansi $0.043<0.05$, maka abnormal return sebelum peristiwa memiliki perbedaan dengan abnormal return setelah peristiwa, sehingga dapat dinyatakan bahwa peristiwa peledakan Bom Kedubes Australia dapat mempengaruhi harga saham di pasar modal Indonesia. 


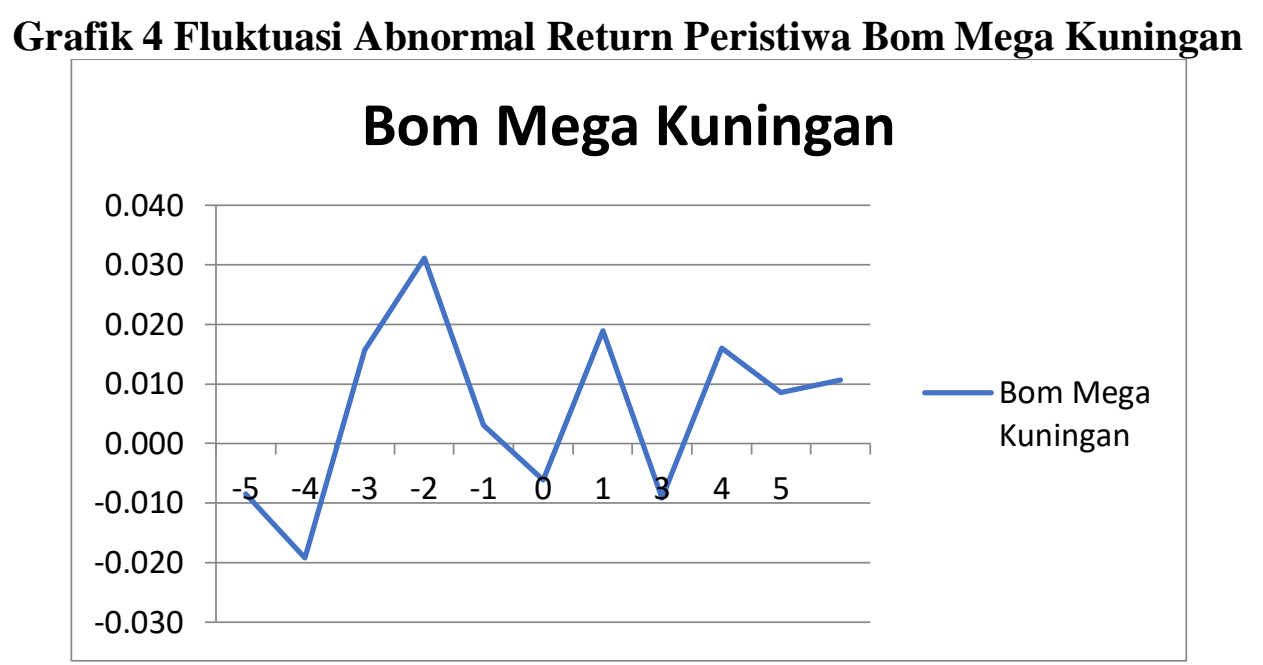

Sumber: (data diolah peneliti, 2017)

Grafik 4 memperlihatkan pergerakan abnormal return selama periode peristiwa Bom Mega Kuningan pada tanggal 17/07/2009. Grafik tersebut memperlihatkan bahwa ketika terjadi peristiwa peledakan Bom JW Marriot, abnormal return menurun dari hari sebelumnya yang bernilai 0.003 menjadi -0.006 , kemudian hari setelah peristiwa terjadi peningkatan abnormal return menjadi 0.019. Terlihat juga bahwa pergerakan abnormal return sebelum peristiwa tidak memiliki perbedaan dengan pergerakan abnormal return setelah peristiwa dikarenakan memiliki pergerakan naik turun yang hampir sama. Hasil penghitungan uji hipotesis dengan paired-sample t test menyatakan bahwa Bom Mega Kuningan memiliki hasil signifikansi $0.183>0.05$, maka abnormal return sebelum peristiwa tidak memiliki perbedaan dengan abnormal return sesudah peristiwa, sehingga dapat dinyatakan bahwa peristiwa peledakan Bom Mega Kuningan tidak dapat mempengaruhi harga saham di pasar modal Indonesia pada periode peristiwa tersebut.

Grafik 5 Fluktuasi Abnormal Return Peristiwa Sarinah

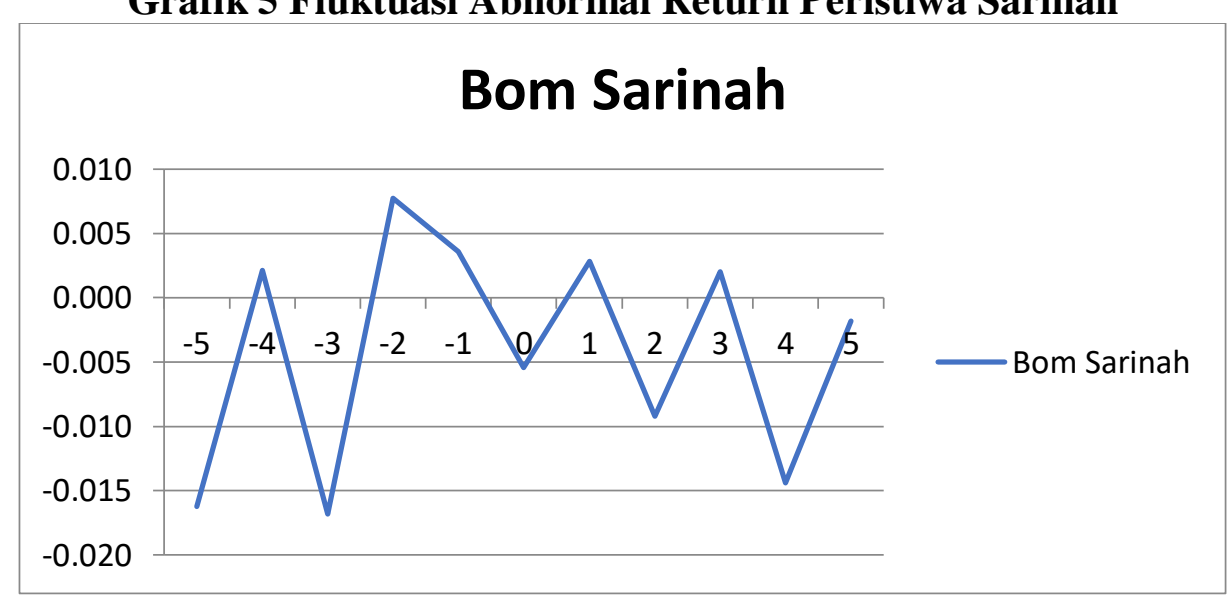

Sumber: (data diolah peneliti, 2017)

Grafik 5 memperlihatkan pergerakan abnormal return selama periode peristiwa Bom Sarinah pada tanggal 14/01/2016. Grafik tersebut memperlihatkan bahwa ketika terjadi peristiwa peledakan Bom JW Marriot, abnormal return menurun dari hari sebelumnya yang bernilai 0.004 menjadi -0.005 , kemudian hari setelah peristiwa terjadi peningkatan abnormal return menjadi 0.003 . Terlihat juga bahwa pergerakan abnormal 
return sebelum peristiwa tidak memiliki perbedaan dengan pergerakan abnormal return setelah peristiwa dikarenakan memiliki pergerakan naik turun yang hampir sama. Hasil penghitungan uji hipotesis dengan paired-sample t test menyatakan bahwa Bom Sarinah memiliki hasil signifikansi $0.874>0.05$, maka abnormal return sebelum peristiwa tidak memiliki perbedaan dengan abnormal return sesudah peristiwa, sehingga dapat dinyatakan bahwa peristiwa peledakan Bom Mega Kuningan tidak dapat mempengaruhi harga saham di pasar modal Indonesia pada periode peristiwa tersebut.

Dari penghitungan dan analisa dampak peristiwa peledakan bom terhadap harga saham di pasar modal Indonesia bahwa yang sangat berpengaruh ketika Bom besar yang terjadi dalam sejarah di Indonesia yaitu Bom Bali I pada tanggal 12/10/2002. Bom tersebut menewaskan 202 orang dan melukai 209 orang, korban pun banyak berasal dari wisatawan warga asing dan juga ada warga lokal. Pasar menjadi efisien dikarenakan investor menyerap informasi yang terjadi ketika peristiwa sehingga terjadi penurunan abnormal return yang drastis, dan terlihat juga perbedaan abnormal return sebelum dan sesudah peristiwa. Para investor juga tidak berasal dari dalam negeri saja, dikarenakan korban banyak berasal dari warga Negara asing, maka investor dari luar negeri pun akan mempertibangkan kembali keputusannya dalam berinvestasi di pasar modal Indonesia. Dari tahun ke tahun peristiwa peledakan bom juga terjadi di Indonesia, tercatat ada 30 peristiwa peledakan bom selama periode 2002-2017 dengan jumlah korban yang berbedabeda. Tetapi hasil penelitian menunjukkan bahwa tidak adanya pengaruh peristiwa peledakan bom baik dari korban sedikit maupun banyak, ini sesuai dengan penelitian Hassan, et al (2015) yang menjelaskan bahwa para investor telah mati rasa terhadap serangan teroris dikarenakan peristiwa yang terjadi terlalu sering (setidaknya setiap tahun terjadi peledakan bom). Sehingga pada tahun 2002 terjadi peledakan dahsyat di Indonesia yang dapat mempengaruhi pasar modal Indonesia, dengan berjalannya waktu hingga 2017 serta banyaknya kejadian peledakan bom, para investor telah peka terhadap serangan tersebut, sehingga tidak mempengaruhi pasar modal Indonesia.

\section{KESIMPULAN DAN SARAN}

\section{Kesimpulan}

Berdasarkan hasil penelitian ini, maka didapatkan beberapa kesimpulan yaitu:

1. Dengan pengujian normalitas, seluruh data selama periode peristiwa terdistribusi normal dengan hasil signifikansi $>0.05$.

2. Dengan pengujian hipotesa menggunakan uji paired-sample t test didapatkan bahwa tidak semua peristiwa peledakan bom di Indonesia berpegaruh terhadap pasar modal Indonesia selama periode 2002-2017.

3. Peristiwa peledakan bom yang memiliki hasil signifikansi $<0.05$ menunjukkan hasil bahwa abnormal return sebelum peristiwa memiliki perbedaan dengan abnormal return sesudah peristiwa, sehingga peristiwa Bom Bali I pada tanggal 12/10/2002 dan Bom Kedubes Australia pada tanggal 09/09/2004 berpengaruh terhadap pasar modal Indonesia.

4. Peristiwa peledakan bom yang memiliki hasil signifikansi $>0.05$ menunjukkan hasil bahwa abnormal return sebelum peristiwa tidak memiliki perbedaan dengan abnormal return sesudah peristiwa, sehingga peristiwa Bom JW Marriot pada tanggal 05/08/2003, Bom Mega Kuningan pada tanggal 17/07/2009 dan Bom Sarinah pada tanggal 14/01/2006 tidak berpengaruh terhadap pasar modal Indonesia. 


\section{Saran}

Berdasarkan hasil penelitian ini, maka didapatkan beberapa saran untuk pengembangan penelitian selanjutnya yaitu:

1. Menghitung seluruh peristiwa dari lamanya periode yang telah ditentukan untuk membandingkan lebih detail peristiwa dari tahun ke tahun dampaknya terhadap pasar modal Indonesia.

2. Selain periswtia peledakan bom, peristiwa politik lainnya juga dapat diteliti dampaknya terhadap pasar modal Indonesia.

3. Selain peristiwa dalam negeri, peristiwa luar negeri juga dapat diteliti dampaknya terhadap pasar modal Indonesia karena adanya integrasi pasar modal.

\section{DAFTAR PUSTAKA}

Abadie, Alberto \& Javier Gardeazabal. 2008. Terrorism and the World Economy. European Economic Review, 52: 1-27.

Ang, Robert. 1997. Buku Pintar Pasar Modal Indonesia. Jakarta: Mediasoft Indonesia.

Anonim. 2017. List of terrorist incidents in Indonesia. https://en.wikipedia.org/wiki/List_of_terrorist_incidents_in_Indonesia Diakses tanggal 31 Oktober 2017.

Ball, R. \& Philip Brown. 1968. An Empirical Evaluation of Accounting Income Numbers. Journal of Accounting Research, 159-177.

Bodie, Z., Kane, A., \& Marcus, AJ. 2014. Investment. Jakarta: Salemba Empat.

Brounen, Dirk, \& Jeroen Derwall. 2010. The impact of terrorist attacks on international stock markets. European Financial Management, 16(4): 585-598.

Brück, Tilman. 2005. An economic analysis of security policies. Defence and peace economics, 16(5): 375-389.

Brück, Tilman, \& Bengt-Arne Wickström. 2004. The economic consequences of terror: guest editors' introduction. European Journal of Political Economy, 20(2), 293300.

Chen, Andrew H. \& Thomas F. Siems. 2004. The effects of terrorism on global capital markets. European journal of political economy, 20(2): 349-366.

Christofis, N., Christos Kollias, Stefanos Papadamou, \& Apostolos Stagiannis et al. 2013. Istanbul Stock Market's reaction to terrorist attacks. Doğuş Üniversitesi Dergisi, 14(2): 153-164.

Drakos, Konstantinos. 2010. Terrorism activity, investor sentiment, and stock returns. Review of Financial Economics, 19(3), 128-135.

Elton, Edwin J. 2009. Modern Portofolio Theory and Investment Analysis. New York: John Wiley \& Sons.

Fama, Eugene F., May 1970. Efficient market: A Review of Theory and Empirical Work. Journal of Finance, 25 (2): 383-417.

Fathi, S., \& Kaveh Shahraki. 2011. The effect of terrorism on financial markets (Case study: Tehran Stock Exchange price index). Interdisciplinary Journal of Contemporary Research in Business, 3(5): 249.

Hartono, Jogiyanto. 2010. Teori Portofolio Dan Analisis Investasi. Yogyakarta: BPFE UGM. 
Hassan, Syeda A. \& Maryam Saeed Hashmi. 2015. Terrorism and the Response of Investors at Capital Market: A Case of Pakistan. Pakistan Journal of Commerce and Social Sciences, 9(1): 218-227.

Hassan, S. A., Atif Mahmood, Ashfaq Ahmed, \& Syed Fakhar Abbas. 2014. Impact of Terrorism on Karachi Stock Exchange: Pakistan. Journal of Basic and Applied Scientific Research, 4(7): 182-191.

Hon, Mark T., Jack Strauss, \& Soo-Keong Yong. 2004. Contagion in financial markets after September 11: myth or reality?. Journal of Financial Research, 27(1), 95114.

Kollias, C., Stephanos Papadamou, \& Apostolos Stagiannis. 2011. Terrorism and capital markets: The effects of the Madrid and London bomb attacks. International Review of Economics \& Finance, 20(4): 532-541.

Mandelbrot, Benoit. 1966. Forecasts of future prices, unbiased markets, and" martingale" models. The Journal of Business, 39(1): 242-255.

Nikkinen, J., Mohammed Omran, Petri Sahlström, \& Janne Äijö. 2006. Global stock market reactions to scheduled US macroeconomic news announcements. Global Finance Journal, 17(1): 92-104.

Samuelson, Paul. A. 1965. Proof that properly anticipated prices fluctuate randomly. IMR; Industrial Management Review (pre-1986), 6(2): 41.

Sandler, Todd. 2003. Collective action and transnational terrorism. The World Economy, 26(6): 779-802.

Sandler, Todd, \& Walter Enders. 2004. An economic perspective on transnational terrorism. European Journal of Political Economy, 20(2), 301-316.

Sjahrir. 1995. Tinjauan Pasar Modal. Jakarta: PT Gramedia Pustaka Utama.

Suryawijaya, Marwan A. \& Faizal Arief Setiawan. 1998. Reaksi Pasar Modal Indonesia Terhadap Peristiwa Politik dalam Negeri (Event study pada peristiwa 27 Juli 1996). Journal Kelola 18: 137-153.

http://www.idx.co.id Diakses tanggal 27 Juli 2017. 